\title{
Oxidatív stressz és atherosclerosis
}

\author{
Stark Júlia dr. \\ Semmelweis Egyetem, Általános Orvostudományi Kar, II. Belgyógyászati Klinika, Budapest \\ Magyar Tudományos Akadémia-Semmelweis Egyetem, Molekuláris Medicina Kutatócsoport, Budapest
}

\begin{abstract}
Az atherosclerosis, ami a mai napig vezető halálok a fejlett országokban, genetikai hajlam és számos ismert környezeti rizikótényező hatására alakul ki. A legtöbb ilyen faktor oxidatív stressz keltése révén endothelialis múködészavarhoz és egyéb proatherogen folyamatokhoz vezet. Az érelmeszesedés elsősorban az artériás rendszer tipikus helyein, az elágazásoknál és kanyarulatoknál alakul ki, ahol a szabályos lamináris áramlás zavart szenved. Emiatt fokozódik az endothelium permeabilitása a kis sưrűségű lipoprotein számára, ami így felhalmozódik az érfal intimarétegében és oxidálódik. Az oxidált kis sûrúségű lipoprotein számos úton hozzájárul az atherosclerosis kialakulásához: elősegíti a monocyták vándorlását az érfalba, a habossejt-képződést, a meszes plakk kialakulását, a plakkdestabilizációt és a thromboticus szövődményeket. Miután az oxidatív stressz az atherosclerosis patogenezisében számos ponton szerepet játszik, felmerül, hogy antioxidáns terápiával megelőzhető-e a betegség. Több klinikai vizsgálat szerint az antioxidánsok - mint az N-acetil-cisztein, C- és E-vitamin, folsav, ösztrogének - hatékonyak a coronariabetegség megelőzésében, de ezt randomizált klinikai vizsgálatok nem tudták bizonyítani. Orv. Hetil., 2015, 156(28), $1115-1119$.
\end{abstract}

Kulcsszavak: oxidatív stressz, érelmeszesedés, LDL-koleszterin, atheroscleroticus plakk, antioxidánsok

\section{Oxidative stress and atherosclerosis}

Atherosclerosis is a leading cause of death in developed countries. Genetic susceptibility and environmental factors play a role in the pathogenesis. Most of these factors lead to endothelial dysfunction and other pro-atherogenic processes by causing oxidative stress. Atherosclerosis typically develops at the curved and branched regions of the arterial tree, where the laminar blood flow is disturbed. This leads to increased permeability of the endothel to low density lipoprotein molecules, which accumulate in the intima and are oxidised by vascular cells. Oxidised low density lipoprotein takes part in many phases of atherogenesis: stimulates the binding of monocytes to the endothel, foam cell formation, the development of plaques, plaque destabilization and thrombotic complications. Since oxidative stress plays an important role in atherogenesis, it has been suggested that antioxidant molecules might have antiatherogenic function. Many clinical investigations have shown that antioxidants such as $\mathrm{N}$-acetylcystein, vitamin $\mathrm{E}$ and $\mathrm{C}$, folic acid, and estrogens can prevent atherosclerosis, however, randomized studies failed to confirm this effect.

Keywords: oxidative stress, atherosclerosis, LDL cholesterol, atherosclerotic plaque, antioxidants

Stark, J. [Oxidative stress and atherosclerosis]. Orv. Hetil., 2015, 156(28), 1115-1119.

(Beérkezett: 2015. április 23.; elfogadva: 2015. május 22.)

A közlemény a Fehér János Alapítvány pályázatán díjazott pályamunka.

\section{Rövidítések}

$\mathrm{ECM}=$ extracelluláris mátrix; eNOS = endothelialis nitrogén-monoxid-szintáz; FGF = fibroblast növekedési faktor; ICAM-1 = intracelluláris adhéziós molekula-1; LOX-1 = lektinszerü ox-LDL receptor; $\mathrm{MCP}-1=$ monocyta kemotaktikus protein $-1 ; \mathrm{MPO}=$ mi- eloperoxidáz; $\mathrm{NO}=$ nitrogén-monoxid; NOS = nitrogén-monoxidszintáz; NOX = NADPH-oxidáz; PDGF = vérlemezke-eredetü növekedési faktor; SOD = szuperoxid-dizmutáz; VCAM-1 = vascularis sejtadhéziós molekula-1; XO = xantinoxidáz 
Magyarországon a keringési rendszer betegségei okozzák az összes halálozás 50,45\%-át [1]. Az atherosclerosis már gyermekkorban elkezdődik zsíros csíkok kialakulásával, és az érelmeszesedés előrehaladottabb eltérései az életkorral egyre gyakoribbak. A 30-34 éves férfiak 20\%ában, a nők $8 \%$-ában már előrehaladott coronariaatheroma található [2]. A meszes plakkok az artériás rendszer tipikus helyein jelennek meg, fóként elágazódásoknál, bifurcatióknál, ahol a védőhatású lamináris véráramlás zavart szenved [3].

\section{Oxidatív stressz az endothelben}

$\mathrm{Az}$ endothel védőréteget képez a vér és a potenciálisan thrombogen subendothelium között. Részt vesz a véralvadás és gyulladásos folyamatok szabályozásában, modulálja az értónust, alaphelyzetben az eret viszonylag tágan tartva, ami fokozott nyírófeszültség esetén a megnövekedett nitrogén-monoxid- (NO-) termelésnek köszönhetően tovább tágul. Ezt nevezzük endothelfüggő vasodilatatiónak [4].

$\mathrm{Az}$ endothelsejtben az oxidatív stressznek kontrollált körülmények között fontos fiziológiás szerepe van. A szabadgyök-termelés forrása a NADPH-oxidáz (NOX), xantinoxidáz (XO) és az úgynevezett „uncoupled” endothelialis nitrogén-monoxid-szintáz (eNOS), ami a NO helyett szuperoxidot termel. A NOX-fehérjék és termékeik (szuperoxid, hidrogén-peroxid) strukturális és jelátviteli molekulaként viselkednek, szabályozzák a sejtnövekedést és -differenciálódást, a sebgyógyulást és az érfal tónusát [5]. A szuperoxid szabályozza a NO értágító hatását. A fokozott NOX-aktivitás azonban kedvezőtlenül befolyásolja az ér szerkezetét: serkenti a vasoconstrictiót, a thrombocytaaggregációt, valamint a szuperoxid-dizmutáz (SOD) által keletkező hidrogénperoxid $\left(\mathrm{H}_{2} \mathrm{O}_{2}\right)$ önmagában is aktiválja a thrombocytákat [6]. A xantinoxidáz $\mathrm{NADH}, \mathrm{O}_{2}$ és xantin/hypoxantin felhasználásával termel szuperoxid aniont és $\mathrm{H}_{2} \mathrm{O}_{2}$-t . A fokozott XO-aktivitás rontja az endothelfüggő vasodilatatiót [5].

Az endothelben fiziológiásan termelődő NO-nak fontos szerepe van az atherosclerosis elleni védelemben. A NO mennyiségét az intracelluláris kalciumszint és a nyírófeszültség szabják meg. Minél magasabb a kalciumszint, illetve minél nagyobb a nyírófeszültség, ép endothel esetén annál több NO termelődik, amely az ér lumenébe áramolva gátolja a thrombocytaaggregációt és a fehérvérsejt-adhéziót és -migrációt. A natív és az oxidált LDL által okozott csökkent L-arginin-felvétel miatt viszont csökken a NOS aktivitása, ami az oxidatív szabad gyökök túltermelődéséhez vezet. A szuperoxidgyök igen nagy affinitással kötődik a NO-hoz, egymás közelében azonnal peroxinitritté egyesülnek. Ha a gyulladás részeként a kalciumtól függetlenül szintetizálódó NO és az oxigén-szabadgyökök szintje meghalad egy bizonyos szintet, a peroxinitritképződés kerül előtérbe [7].
A peroxinitrit hatására, az úgynevezett NO„uncoupling” során az eNOS a jótékony NO helyett szuperoxidot termel. A folyamatot fokozott oxidatív stressz és a NOS kofaktorainak hiánya jellemzi, ennek következtében az egyensúly eltolódik a peroxinitrittermelődés felé. A peroxinitrit károsítja a mitokondriális légzési láncot és a sejtlégzést, a SOD-ot, a redukált glutationt, továbbá aktivál vagy inaktivál jelátviteli fehérjéket, valamint DNS-fragmentációt okoz, végső soron apoptózist indukál. A peroxinitrit egyúttal a gyulladás fokozódásához vezet, a SOD révén képződő $\mathrm{H}_{2} \mathrm{O}_{2}$ pedig a gyulladásos citokinek elválasztását fokozza (TNF- $\alpha$, interleukin-6, interleukin-1- $\beta$, iNOS, intracelluláris adhéziós molekula-1 [ICAM-1], P-szelektin stb.). A nitrogéntartalmú szabad gyökök a nitroziláció révén módosítják a struktúrfehérjéket, így például a metalloproteinázok, amelyek az atheroscleroticus plakksapkát gyengítik és a plakkrupturát elősegítik, nitroziláció hatására aktiválódnak [7].

A keringő vagy a leukocytából kiáramló és a gyulladt endotheliumhoz tapadó mieloperoxidáz (MPO) átjut az endothelialis barrieren és a subendothelialis mátrixban helyezkedik el, ahol funkcionális és szerkezeti változásokat idéz elő az artériafalban. Az atheroscleroticus plakkban nagy mennyiségú 3-klorotirozin található, ami az MPO aktivitását bizonyítja. Az MPO aktivitása az érfalban negatívan érinti a gyulladás ellen védő mechanizmusokat: a NO inaktiválásához, LDL-oxidációhoz, a HDL gyulladásgátló tulajdonságának csökkenéséhez vezet. Az MPO a metalloproteinázok aktiválásán keresztül elősegítheti a plakkdestabilizációt, -eróziót [6].

\section{Endotheldiszfunkció}

A NO hozzáférhetőségének csökkenése az endothelben az értágító funkció zavarához vezet. Ez az endotheldiszfunkció az atherosclerosis kialakulásának első lépése [8]. $\mathrm{Az}$ érelmeszesedés ismert rizikótényezői közül a legtöbb endotheldiszfunkcióval társul: öregedés, férfi nem, coronariabetegség a családi anamnézisben, dohányzás, dyslipidaemia, gyulladásos és immunológiai tényezók, cukorbetegség, emelkedett szérumhomocisztein-szint, hypertonia [4]. A hypercholesterinaemia, hypertriglyceridaemia, hyperglykaemia és az öregedés mind mitokondriális múködészavart okoznak. A mitokondriális reaktív oxigéngyökök krónikus túltermelődése a pancreas $\beta$-sejtjeinek pusztulásához, az LDL fokozott oxidációjához, az érfali simaizomsejtek károsodásához, az endothelsejtek apoptózisához és múködési zavarához vezet [9]. A dohányzás hatására fokozódik az LDL oxidatív modifikációja és csökken az LDL-oxidáció ellen védő paraoxanáz enzim aktivitása. Az oxidált LDL (ox-LDL) megszakítja az endothelsejt felszínét, serkenti a thrombocytaaggregációt, gyulladásos és immunológiai változásokat idéz elő a macrophagokból való citokinfelszabadítás és antitesttermelés révén. A proinflammatorikus citokinek serkentik a sejtproliferációt, reaktív oxigéngyö- 
kök termelődését, a mátrixmetalloproteinázokat és a szövetifaktor-expressziót [4].

Tehát a coronariabetegség ismert rizikótényezői oxidatív stressz keltése révén endothelialis múködészavarhoz és számos egyéb patogenetikai folyamathoz vezetnek, amelyek mind az atherogenesis irányába hatnak.

\section{A kóros véráramlás hatásai}

A véráram által az érfalra kifejtett tangenciális súrlódási erőt nyírófeszültségnek nevezzük. A nyírófeszültséget az endothelsejtek mechanoszenzorokkal érzékelik, amelyek lehetnek G proteinhez kötött receptorok, ioncsatornák, növekedésifaktor-receptorok, kaveolák, integrinek, citoszkeletonhálózat stb. Ezek olyan összetett jelátviteli kaszkádot indítanak, aminek az eredménye a reaktív oxigén- és nitrogénszármazékok termelődése. Az oxidációs és nitrozilációs reakciók különböző célfehérjéken hatva gén- és fehérjeexpressziós változásokhoz vezetnek, amelyek anti-, illetve proatherogen hatásokat válthatnak ki az endothelsejtben (1. ábra) [5].

$\mathrm{Az}$ érrendszerben a hemodinamikai körülmények igen összetettek a változatos geometriai szerkezetnek köszönhetően. Az artéria egyenes szakaszán az áramlás jellemzően lamináris, 10-70 dyne $/ \mathrm{cm}^{2}$ átlagos nyírófeszültséggel. A kanyargós, elágazó érszakaszokon azonban a véráramlás zavart szenved, örvények alakulnak ki, ami alacsony és oszcilláló nyírófeszültséghez vezet. In vivo megfigyelések szerint az atheroscleroticus laesiók elsősorban ezeken a szakaszokon alakulnak ki [5].
A tartós lamináris áramlásnál jellemző állandó nyírófeszültség ( 5 dyne $/ \mathrm{cm}^{2}$ ) átmeneti NOX-aktivitás-fokozódáshoz vezet. Ugyanakkor antiinflammatorikus és antioxidáns transzkripciós faktorok is aktiválódnak az endothelben, amelyek számos, az antioxidáns védelemben szerepet játszó enzim vagy fehérje génjét aktiválják $[5,10,11]$. Tartós lamináris áramlás esetén az eNOS aktivitása is fokozódik. A NO és reaktív nitrogéngyökök hatására tartósan csökken a mitokondriális I, II/III és IV légzési komplexek aktivitása, gátlódik a mitokondriális elektrontranszport az endothelsejtekben. Tehát a folyamatos lamináris áramlás antioxidáns hatású [5].

A pulzatilis (egyirányú, egy szívciklus alatt 15-70 dyne $/ \mathrm{cm}^{2}$ között változó) és a magas (30 dyne $/ \mathrm{cm}^{2}$ ) nyírófeszültség downregulál néhány NOX-alegységet, csökkenti a szuperoxidtermelődést, upregulálja az eNOS-expressziót és fokozza a NO-szintézist. Bár a szabad gyökök szintje mérsékelten emelkedik a szabályos áramlásnak kitett endothelsejtekben, a magas, még nem kóros nyírófeszültség esetén az antioxidáns folyamatok dominálnak. Az oxigéngyökök ekkor messenger molekulaként viselkednek az erek hemodinamikai változásokhoz való alkalmazkodásában, tehát fontos szerepet játszanak az érrendszer élettanában. Az egyirányú, lamináris felületi nyírófeszültség tehát antiatherogen és antiinflammatorikus gének aktivációjához, alacsonyabb szabadgyök-termelődéshez és jobb NO-biohasznosuláshoz vezet, ami antioxidatív állapotot eredményez [5].

Az artériás elágazódásoknál és kanyarulatoknál a lamináris áramlás meglassul, turbulenssé válhat, akár irányt is

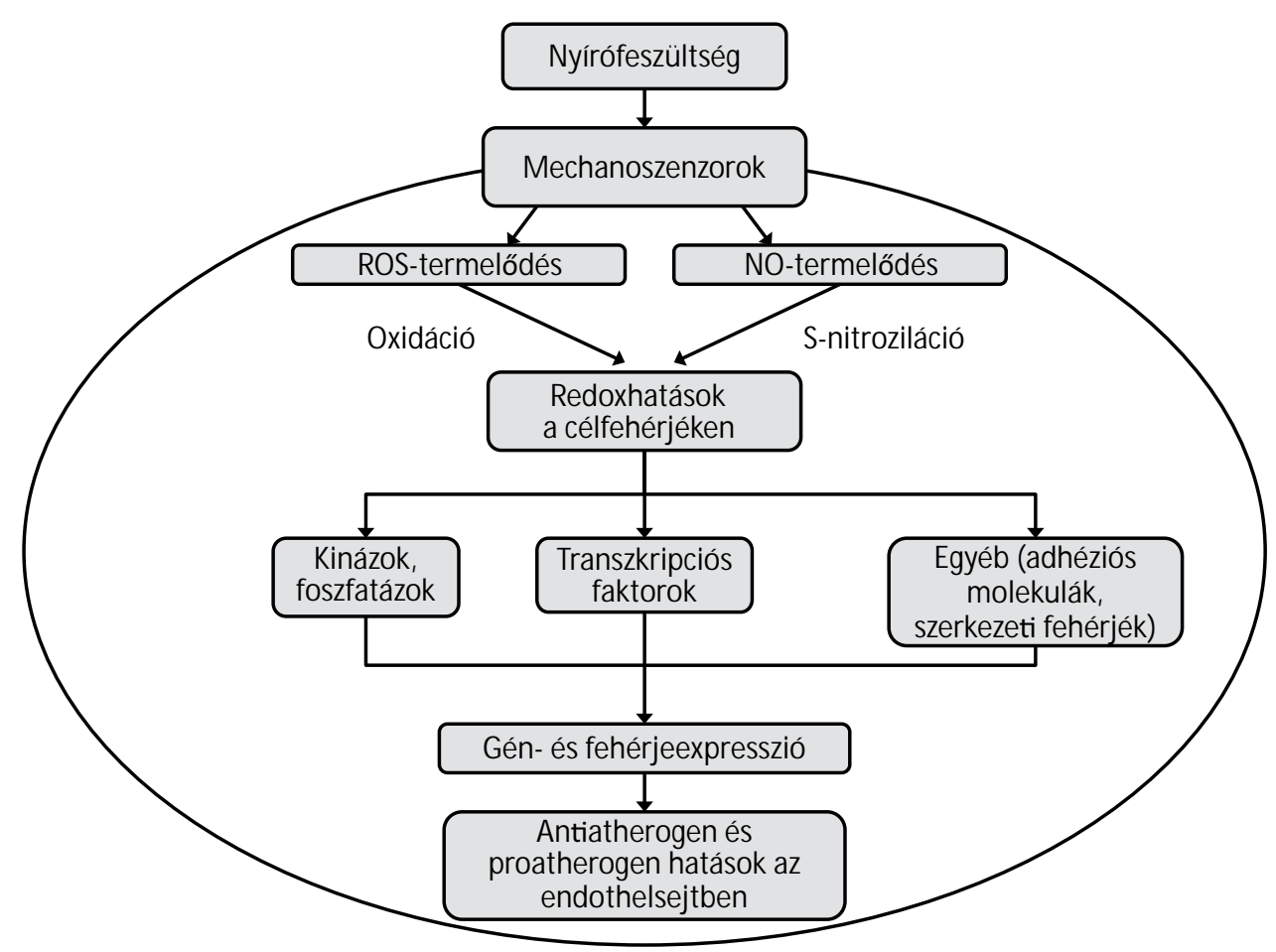

1. ábra

| A nyírófeszültség hatása az endothelsejtben. Az ellipszis jelképezi az endothelsejtet 
változtathat, az endothelre ható nyírófeszültség csökken (időbeni átlaga $<10-12$ dyne $/ \mathrm{cm}^{2}$ ). Ennek hatására különböző proatherogen folyamatok kerülnek előtérbe. Csökken az eNOS expressziója és a NO biológiai hozzáférhetôsége, az értágító hatású prosztaciklin alulregulálódik, a vazokonstriktív endothelin-1 fölfelé szabályozódik. Az alacsony nyírófeszültség hatására az endothelsejtben olyan folyamatok mennek végbe, amelyek az LDL-receptort upregulálják és fokozzák az endothelium permeabilitását az LDL számára. Megváltozik az endothelsejtek alakja, a sejtek közötti kapcsolatok fellazulnak, fokozódik az LDL subendothelialis infiltrációja [12]. A visszafelé irányuló áramlás által okozott negatív nyírófeszültség upregulálja a Nox4-alegységet, tartósan megemeli a NOX és a XO aktivitását, fokozza a mitokondriális szuperoxidtermelést, és csökkenti a NOkoncentrációt. Az oszcilláló áramlás során a szuperoxid és a NO közti egyensúly eltolódása peroxinitrit keletkezéséhez vezet. A reaktív oxigéngyökök mérsékelt emelkedése mediálja az atherogen monocyta kemotaktikus protein-1 (MCP-1) és ICAM-1 expresszióját [5].

$\mathrm{Az}$ alacsony nyírófeszültség az $\mathrm{NF} k \mathrm{~B}$ aktivációján keresztül fokozza a sejtadhéziós molekulákat és gyulladásos citokineket kódoló gének expresszióját. Ennek hatására monocyták vándorolnak az intimába, macrophagokká differenciálódnak, amelyek azután fenntartják a gyulladást és az oxidatív stresszt [12].

Zavart áramlási jelek mellett tehát fokozódik a proatherogen gének transzkripciója, magasabb a szabad gyökök szintje, és rosszabb a NO biohasznosulása, tehát oxidatív állapot jön létre. Összességében atheroscleroticus elváltozások alakulnak ki, amihez azonban még egyéb tipikus kockázati tényezőkre is szükség van [5, $12]$.

\section{Az LDL-oxidáció következményei}

A korai atherosclerosis első lépéseként az LDL-részecskék a sérült endothelen, illetve az endothel lektinszerú ox-LDL receptorán (LOX-1) bejutnak az érfalba. A telített zsírsavak fokozzák a LOX-1 expresszióját azáltal, hogy selejtes (misfolded) peptidek felhalmozódásával járó, úgynevezett endoplazmásreticulum-stresszt okoznak. A telítetlen zsírsavak ezzel szemben megelőzik a LOX-1 expresszióját a telített zsírsavakkal kezelt macrophagokban, és gátolják a LOX-1-upregulációt [13].

$\mathrm{Az}$ endothelen átjutott LDL a B100 apolipoproteinen keresztül kötődik az extracelluláris mátrix (ECM) proteoglikánjaihoz, majd a vascularis sejtek által enyhén oxidálódik $[3,6]$. A subintimalis ECM-ben csapdába esett LDL-részecskék stimulálják a vascularis sejtek ICAM-1, vascularis sejtadhéziós molekula-1 (VCAM-1), MCP-1, granulocyta- és macrophagkolónia-stimuláló faktorok termelését. Ennek köszönhetően napokon vagy heteken belül monocyták tapadnak ki az endothelium felületére, majd átvándorolnak az endothelen az intimába, ahol proliferálnak, macrophagokká differenciálód- nak. Ezek tovább oxidálják az LDL-t az MPO és a reaktív oxigén-szabadgyökök által. Az ox-LDL a macrophag scavenger receptoraihoz kötődve bejut a sejtbe. Mivel a scavenger receptorok nem downregulálódnak az intracelluláris koleszterinszint növekedésére, a koleszterin felhalmozódik, és úgynevezett habos sejtek képződnek. Emellett habos sejtek keletkezhetnek natív LDL internalizálása, aggregált LDL vagy LDL-immunkomplexek felvétele révén is $[3,9]$.

Idővel a habos sejtek elpusztulnak, és lipiddús tartalmuk az elváltozás nekrotizáló magjába kerül. Az ox-LDL fokozza a vérlemezke-eredetû́ növekedési faktor (PDGF) és fibroblast növekedési faktor (FGF) expresszióját az endothelsejtekből és macrophagokból. Ezek hatására a simaizomsejtek a tunica mediából az intimába vándorolnak és itt proliferálnak. A habos sejtek, thrombocyták és simaizomsejtek alkotják a zsíros csíkot.

Az ox-LDL serkenti a simaizomsejtek kollagéntermelését is, így fibrosus plakkok keletkeznek. Ezek eleinte az adventitiaréteg felé terjednek, de egy kritikus ponton túl kifelé kezdenek növekedni, és a lumenbe türemkednek. A laesio fokozatosan növekszik a vérből kitapadó mononukleáris sejteknek köszönhetően. Ezt sejtproliferáció, ECM termelése és extracelluláris lipidek lerakódása követi. A habos sejtek, az extracelluláris lipidek és sejttörmelék együtt meszes plakkot alkotnak [9].

Az ox-LDL hozzájárul a plakkdestabilizációhoz és a thromboticus szövődményekhez is. Serkenti a mátrixmetalloproteináz-1 és -9 szekrécióját, így elősegíti a simaizomsejtek apoptózisát és a fibrosus sapka gyengülését. A foszfolipáz-A2 aktiválásán keresztül elősegíti az arachidonsav kiáramlását és a prosztaciklin, prosztaglandinok szintézisét. Ezek a folyamatok fokozzák a thrombocytaaggregációt és -adhéziót. Emellett az ox-LDL csökkenti a szöveti plazminogénaktivátor és növeli a plazminogénaktivátor inhibitor- 1 aktivitását, ami az endothelium fibrinolitikus hatásának csökkenéséhez vezet. Összességében ezek a folyamatok megmagyarázzák az előrehaladott plakkok thromboticus szövődményeit $[3,13]$.

\section{Antioxidáns hatású gyógyszerek}

A klinikum szempontjából fontos kérdés, hogy az atherosclerosis patogenezisében szerepet játszó oxidatív stressz csökkentésével megelőzhető-e a betegség kialakulása. Több klinikai vizsgálat leírja, hogy az antioxidánsok hatékonyak a cardiovascularis események megelőzésében coronariabetegeknél, de ezt randomizált klinikai vizsgálatok nem tudták bizonyítani. Valószínü, hogy e vizsgálatok során az antioxidánskezelést a nagyon alacsony rizikójú csoportba tartozó betegek kapták. A nagyon magas rizikócsoportba tartozóknál, mint a végstádiumú veseelégtelenségben szenvedő, dializált betegeknél az E-vitamin- és az N-acetil-cisztein-kezelés csökkentette a cardiovascularis történések rizikóját [3].

Az N-acetil-cisztein, az L-cisztein prekurzora serkenti a NO aktivitását és a szabad gyökök semlegesítését. Az 
$\mathrm{N}$-acetil-cisztein pótlása javítja a coronariák endothelfüggó dilatatióját [14].

$\mathrm{Az}$ antioxidáns hatású ösztrogén szintén fokozza az endothelfüggő vasodilatatiót. Ennek hátterében a fokozott NO-szintézis és -felszabadulás, valamint a coronaria-endothelin-1-szint csökkentése állhat. A szójafehérjékben található fitoösztrogének csökkentik a koleszterinszintet és gátolják az LDL-oxidációt [15].

A C-vitamin a glutationnal való kölcsönhatás során szabályozza az intracelluláris redoxállapotot, képes a szabad gyökök semlegesítésére, és visszafordítja a dohányzás által okozott elváltozásokat. Hypercholesterinaemiás betegeknél a C-vitamin és a folsav javítja az endothelfunkciót és a plazmalipidek szintjét, valószínúleg az oxidatív stressz csökkentésén és a NO-lebomlás gátlásán keresztül [15].

Klinikai vizsgálatok szerint az E-vitamin (alfa-tokoferol) napi adagolása (900 mg négy hétig) megelőzi az LDL-akkumulációt a habos sejtekben, és napi $300 \mathrm{mg}$ dózisban javítja az áramlásfüggő értágulást a perifériás artériákban. A vérlemezke bekebelezi az E-vitamint, ezáltal gátlódik a thrombocytaaggregáció. Az E-vitamin csökkenti a monocyta felszínén az adhéziós molekulák expresszióját, így gátlódik a monocyta-endothel adhézió. Emellett az E-vitamin gátlóhatással van a simaizomsejt-proliferációra a proteinkináz $\mathrm{C}$ gátlásán keresztül [15].

A megfigyeléses vizsgálatok során tapasztalt kedvező eredmények ellenére randomizált klinikai vizsgálatok nem erősítették meg a C- és E-vitamin-pótlás jótékony hatását a koszorúér-betegség megelőzésében. Ennek ellenére az ismert cardiovascularis betegek és a nagyon magas rizikócsoportba tartozók esetén az antioxidánskezelés jótékony hatású [3].

Anyagi támogatás: A dolgozat megírása, illetve a kapcsolódó kutatómunka anyagi támogatásban nem részesült.

A szerző a kézirat végleges változatát elolvasta és jóváhagyta.

Érdekeltségek: A szerzőnek nincsenek érdekeltségei.

\section{Irodalom}

[1] Molnár, T. M. Barna, K.: Demographic characteristics in Hungary and the European Union, in particular considering the mortality of cancer. [Demográfiai jellemzők Magyarországon és az Európai Unióban, különös tekintettel a daganatos megbetegedések okozta halálozásra.] Statisztikai Szemle, 2011, 90(6), 544558. [Hungarian]
[2] McGill, H. C. Jr., McMahan, C. A., Zieske, A. W., et al.: Association of coronary heart disease risk factors with microscopic qualities of coronary atherosclerosis in youth. Circulation, 2000, 102(4), 374-379.

[3] Maiolino, G., Rossitto, G., Caielli, P., et al.: The role of oxidized low-density lipoproteins in atherosclerosis: the myths and the facts. Mediators Inflamm., 2013, 2013, 714653.

[4] Zhao, X.: Pathogenesis of atherosclerosis. UpToDate. 2014. http:// www.uptodate.com/contents/pathogenesis-of atherosclerosis? source $=$ search_result\&search $=$ pathogenesis + of + atherosclerosis\& selectedTitle $=1 \sim 150$

[5] Hsieh, H. J., Liu, C. A., Huang, B., et al.: Shear-induced endothelial mechanotransduction: the interplay between reactive oxygen species (ROS) and nitric oxide (NO) and the pathophysiological implications. J. Biomed. Sci., 2014, 21, 3.

[6] Violi, F., Pignatelli, P.: Clinical application of NOX activity and other oxidative biomarkers in cardiovascular disease? A critical review. Antioxid. Redox Signal., 2014 Feb 24. [Epub ahead of print]

[7] Kiss, R. G., Béres, B. J.: The ambivalent effects of nitrogen monoxide: integrity and toxicity. [A nitrogén-monoxid ellentétes hatásai: integritás és toxicitás.] Lege Artis Medicinae, 2007, 17(67), 397-402. [Hungarian]

[8] Kitta, Y., Obata, J. E., Nakamura, T., et al.: Persistent impairment of endothelial vasomotor function has a negative impact on outcome in patients with coronary artery disease. J. Am. Coll. Cardiol., 2009, 53(4), 323-330.

[9] Bullon, P., Newman, H. N., Battino, M.: Obesity, diabetes mellitus, atherosclerosis and chronic periodontitis: a shared pathology via oxidative stress and mitochondrial dysfunction? Periodontology 2000, 2014, 64(1), 139-153.

[10] Fledderus, J. O., Boon, R. A., Volger, O. L., et al.: KLF2 primes the antioxidant transcription factor $\mathrm{Nrf} 2$ for activation in endothelial cells. Arterioscler. Thromb. Vasc. Biol., 2008, 28(7), 13391346.

[11] May, O. L: Nrf2 antioxidant stress response: Managing its "dark side". https://www.caymanchem.com/app/template/Article. $\mathrm{vm} /$ article $/ 2168$; jsessionid $=55 \mathrm{BADB} 4183 \mathrm{BD} 678 \mathrm{D} 2955 \mathrm{D} 65$ 0DA29B6F7

[12] Chatzizisis, Y. S., Coskun, A. U., Jonas, M., et al.: Role of endothelial shear stress in the natural history of coronary atherosclerosis and vascular remodeling: molecular, cellular, and vascular behavior. J. Am. Coll. Cardiol., 2007, 49(25), 2379-2393.

[13] Afonso, M. da S., Castilho, G., Lavrador, M. S., et al.: The impact of dietary fatty acids on macrophage cholesterol homeostasis. J. Nutr. Biochem., 2014, 25(2), 95-103.

[14] Andrews, N. P., Prasad, A., Quyyumi, A. A.: N-acetylcysteine improves coronary and peripheral vascular function. J. Am. Coll. Cardiol., 2001, 37(1), 117-123.

[15] Tangney, C. C., Rosenson, R. S.: Nutritional antioxidants in coronary heart disease. UpToDate. 2013. http://www.uptodate.com/ contents/nutritional-antioxidants-in-coronary-heart-disease?source $=$ search_result\&search $=$ nutritional + antioxidant\&selectedTit le $=2 \sim 150$.

(Stark Júlia dr., Budapest, Szentkirályi u. 46., 1088 e-mail: starkjulia2@gmail.com) 